\title{
A numerical index for evaluating phytoplankton response to changes in nutrient levels in deep mediterranean reservoirs
}

\author{
Aldo MARCHETTO*, Bachisio M. PADEDDA ${ }^{1)}$, Maria A. MARIANI ${ }^{1)}$, Antonella LUGLIÈ ${ }^{1)}$ and Nicola SECHI ${ }^{1)}$ \\ CNR Istituto per lo Studio degli Ecosistemi, Largo V. Tonolli 50, 28922 Verbania-Pallanza, Italy \\ ${ }^{1)}$ Università degli Studi di Sassari, Dipartimento di Botanica ed Ecologia Vegetale, Via Muroni 25, 07100 Sassari, Italy \\ *e-mail corresponding author: a.marchetto@ise.cnr.it
}

\begin{abstract}
This paper proposes a new ecological index based on phytoplankton (MedPTI) as suggested by the European Directive 2000/60/CE, Water Framework Directive (WFD). The index is a useful tool to verify the impacts of eutrophication in Mediterranean reservoirs belonging to different categories of the WFD. Multiple data sets were employed to develop the MedPTI index. The calibration data set included data collected from 30 Sardinian reservoirs in 1994. A list of 44 selected taxa was obtained and used for index calculation. A second dataset including 48 averaged annual values from 10 reservoirs was used. Results showed good correlation between MedPTI and concentration of total phosphorus, which was the limiting nutrient in these reservoirs. The trophic classifications determined using the index agreed with the results from the OECD probabilistic model on the same series of data. Finally, the index was included in an international exercise to compare the definition of reference conditions and quality class boundaries against indices used in other Mediterranean countries.
\end{abstract}

Key words: eutrophication, Water Framework Directive, Mediterranean ecoregion

\section{INTRODUCTION}

The Water Framework Directive (WFD, European Commission 2000) has set a new standard for water quality protection in Europe. The legal action has shifted from defining qualitative and quantitative limits for pollutant discharge to a requirement that the ecological quality of aquatic ecosystems must be maintained or recovered. Furthermore, water quality is not defined in relation to abstract standards, but to the pristine, or "reference", conditions of each specific water body. The goal is that human impact should only have minimal or slight influence on water quality, in high and good conditions, respectively.

The WFD only considers a small number of human pressures as representing the most important factors affecting lake ecosystems in Europe: eutrophication, acidification, toxic pollution, and hydro-morphological alteration. To fully apply the concept on which the WFD is based, however, a solid comprehension is needed of both the ecological processes and the effects of human impacts. Obviously, such a thorough understanding is not available for all European aquatic ecosystems. However, annex 5 of the WFD specifies that ecological status should be measured through a set of Ecological Quality Ratios (EQRs), i.e., the ratio between the value of a given biological indicator in the study site and the value of the same biological indicator in reference conditions. It is obviously questionable (e.g., Moss 2008) whether the ecological status can be reduced to a number of separate biological indicators; good ecological conditions cannot be defined only on the basis of the integrity of each community, but must take into account ecosystem processes and functions as well. According to the WFD, water bodies with conditions classified as moderate to bad should be recovered through actions taken towards the waterbody itself as well as its watershed. The effectiveness of any recovery action should be monitored by testing for improvement in water quality. To limit monitoring costs during recovery, the WFD states that it is not necessary to monitor all biological parameters, only those most sensitive to the pressure(s) acting on each waterbody ("operative monitoring").

When the dominant human pressure is the input of nutrients, phytoplankton is the natural choice for operative monitoring. Phytoplankton reacts directly to nutrient levels through changes in its biomass and composition (Reynolds et al. 2002), and its growing cycle is shorter than that of aquatic macrophytes, allowing faster response. However, long-term monitoring and paleolimnological studies show that phytoplankton response to changing nutrient level is not simple: changes in phytoplankton biomass and composition can show different patterns (e.g., Dokulil \& Teubner 2006), and these changes are generally delayed (Reynolds 2002) with respect to the change in nutrients. Biomass usually reacts faster than species composition to changes in nutrient levels (Sas 1989), but species-specific differences have also been found (Dokulil \& Teubner 2006).

These considerations underline the necessity of identifying simple tools to monitor large scale recovery of thousands of lakes in the next years, in order to evaluate the effectiveness of the actions taken, using both phytoplankton biomass and composition. If chlorophyll- $a$ concentration in the pelagic can be considered 
a good proxy for phytoplankton biomass estimate, the use of species composition in large scale monitoring requires the development of specific trophic indices, which must take into account the specific biogeographic, hydromorphological and climatic features controlling phytoplankton development in specific water bodies. These indices are based on the consideration that, along a gradient in nutrient concentration, each status can be characterized by a specific composition of the algal communities (Reynolds 2002).

In general, two types of indices can be identified. The first includes indices based on the trophic preferences of each species. To construct them, the abundance of each species in lakes of different nutrient level is evaluated, given a trophic score, and in some cases, an indicator value. Indices of this type are used in Norway (Brettum 1989), Austria (revised Brettum index: Dokulil et al. 2005), Germany (PTSI: Riedmüller et al. 2006), Sweden (TPI: Willeïn 2007), and for the deep lakes of northern Italy (Salmaso et al. 2006). All these indices are based on data from a number of lakes (calibration data set) belonging to a relatively uniform region in order to minimize the effects of biogeographic and climatic features. These data are used to estimate the trophic values and the indicator values of the species, either by weighted averages (ter Braak 1987) or using the lake score in a constrained ordination, considering the gradient in nutrient concentartions as the explicative variable (Salmaso et al. 2006). Brettum's index expands this concept with a percent frequency of finding each species in lakes belonging to 5 arbitrary trophic classes (Brettum 1989; Brettum \& Andersen 2004; Dokulil \& Teubner 2006). Indices belonging to the second type, on the contrary, are based on percent biovolume of a given algal group, or on the ratios between the biovolumes of two algal groups. These indices simplify the enumeration of the algae, allowing the evaluation of water quality using higher levels of taxonomic hierarchy. They need to be used with care, because all algal groups include species with different ecological preferences.

Typical indices of this kind are used in France (ITP or Barbe index: Philippe et al. 2003) and Spain (Iga or Catalàn index: Agencia Catalana de l'Aigua 2003). In particular, the Catalàn index, calibrated on reservoirs of the Autonomous Region of Catalonia, is the first index developed specifically for Mediterranean sites (Agència Catalana de l'Aigua 2003). The Phytoplankton Assemblage Index developed by Padisák et al. (2006) is also based on functional groups, but it requires species level identification and biomass estimation.

Mediterranean reservoirs are peculiar environments; they are affected by extreme changes in water level and dynamics due to the passage from a wet season (generally, from late autumn to the beginning of spring), when the reservoirs fill up, to an arid period (generally, from late spring to the beginning of autumn), with no precipitation and marked water uptake used for human activities such as irrigation and drinking supplies (Naselli-Flores \& Barone 2005). Summer level fluctuations in particular may cause the breakdown of thermal stratification, causing even deep reservoirs to behave like shallow lakes (Naselli-Flores 2003). These effects are enhanced in relatively shallow reservoirs, with strong water uptake and rapid level changes, such as those found in Sicily (Naselli-Flores \& Barone 2005).

In other Mediterranean reservoirs, such as in Sardinia, this effect appears to be less pronounced as a consequence of a wide range of causes, from lower water demands due to lower population densities to different water management strategies (use of a pluriannual rather than annual cycle, and/or a focus on the stabilization of water volumes and minimization of level fluctuations). Furthermore, Sardinian reservoirs are generally deeper and more systemically interconnected than Sicilian ones (Marchetti et al. 1992). Consequently, level fluctuations in Sardinia can be smoother and less influential to phytoplankton development than in Sicily (Naselli-Flores \& Barone 2000). However, arid periods lead to significant decreases in the amount of water stored also in Sardinia (Sechi \& Lugliè 1992), allowing higher nutrient concentrations given the same nutrient load.

In this paper we test the ability of some selected numerical indices (namely Barbe, Brettum, Catalàn and Salmaso) to follow the phytoplankton response in terms of species composition to the changes in nutrient level in reservoirs of the Mediterranean region. In addition to testing existing indices, we propose a new index called MedPTI. Based on the widely used technique of weighted averaging (ter Braak 1987), MedPTI is calibrated on the basis of a survey of 30 Sardinian reservoirs in 1994 (Tab. 1, Fig. 1). An independent data set including 48 annual data, collected from the same reservoirs in other years, was used to validate the calibration. Changes in hydrological regimes are not explicitly taken into account other than whatever effect they have on nutrient concentration, since the index is only designed to evaluate the effects of changes in nutrient availability following, for example, the adoption of restorative actions such as sewage diversion or depuration.

The aim was to develop an index to evaluate the effects of eutrophication in deep reservoirs that are located at altitudes lower than $800 \mathrm{~m}$ a.s.l. in mainland and insular Italy (latitudes lower than $44^{\circ}$ North), that have mean depths greater than $15 \mathrm{~m}$, and with conductivity less than $2.5 \mathrm{mS} \mathrm{cm}^{-1}$. In other words, lakes included in types ME-4 and ME- 5 of the official Italian typology, and within L-M5, L-M7 and L-M8, as defined in the exercise of intercalibration in the WFD implementation procedures (ECOSTAT 2003, 2004).

\section{METHODS}

\subsection{Sampling and analyses}

Samples for phytoplankton and water analyses were obtained from stations close to the deepest part of the 
Tab. 1. Reservoirs included in the calibration and validation $\left(^{\circ}\right)$ data sets, and selected morphological data and related years used to formulate MedPTI index. (Use: $\mathrm{A}=$ alimentary; $\mathrm{E}=\mathrm{electric}$ energy; $\mathrm{IN}=$ industrial; $\mathrm{IR}=$ irrigation; Trophic state: HE=hypereutrophic; $\mathrm{E}=$ eutrophic; $\mathrm{M}=$ mesotrophic). Study year 1994 refers to the calibration data set, time series to the validation data set (see text). (* referred to $1994, Z_{\text {mix }} / Z_{\text {eu }}$ : ratio between mixing and euphotic depth).

\begin{tabular}{|c|c|c|c|c|c|c|c|c|c|c|c|}
\hline Reservoir & Code & $\begin{array}{l}\text { Altitude } \\
\text { (m a.s.1.) }\end{array}$ & $\begin{array}{c}\text { Watershed } \\
\left(\mathrm{m}^{2} 10^{6}\right)\end{array}$ & $\begin{array}{l}\text { d Volume } \\
\left(\mathrm{m}^{3} 10^{6}\right)\end{array}$ & $\begin{array}{l}\text { Area } \\
\left(\mathrm{km}^{2}\right)\end{array}$ & $\begin{array}{l}\text { Mean depth } \\
\text { (m) }\end{array}$ & Use & $\begin{array}{l}\text { Trophic } \\
\text { state }\end{array}$ & $\begin{array}{l}\text { Study period } \\
\text { (years) }\end{array}$ & $\begin{array}{l}\text { Summer } \\
\text { stratif.* }\end{array}$ & $Z_{\text {mix }} / Z_{\mathrm{eu}}$ * \\
\hline Alto Flumendosa ${ }^{\circ}$ & ALT FLU & 802 & 180 & 61.4 & 3.2 & 19.2 & E, A & $\mathrm{M}$ & $1992 / 96(5)$ & yes & $0.8-12.5$ \\
\hline Bau Pressiu & BAU PRE & 249 & 29 & 6.2 & 0.2 & 31.0 & A & $\mathrm{M}$ & $1994(1)$ & yes & $0.9-2.3$ \\
\hline Benzone & BEN & 150 & 89 & 1.1 & 0.3 & 4.0 & $\mathrm{E}, \mathrm{A}, \mathrm{IN}$ & $\mathrm{E}$ & $1994(1)$ & yes & $0.4-2.5$ \\
\hline Bidighinzu $^{\circ}$ & BID & 334 & 52 & 12.2 & 1.7 & 7.3 & A & $\mathrm{HE}$ & $1988 / 06(4)$ & yes & $2.4-7.5$ \\
\hline Casteldoria & CAS & 25 & 2378 & 8.3 & 0.4 & 20.8 & IR, E, A, IN & $\mathrm{E}$ & $1994(1)$ & no & $4.1-8.4$ \\
\hline Cedrino $^{\circ}$ & CED & 103 & 631 & 30.0 & 1.1 & 26.5 & A, IR & $\mathrm{E}$ & $1994 / 06(2)$ & yes & $1.7-5.4$ \\
\hline Cixerri & CIX & 40 & 426 & 25.3 & 4.2 & 6.0 & IR, A & $\mathrm{HE}$ & $1994(1)$ & no & $1.8-5.8$ \\
\hline Coghinas & COG & 170 & 1729 & 258.7 & 17.2 & 15.0 & $\mathrm{~A}, \mathrm{IR}, \mathrm{E}, \mathrm{IN}$ & $\mathrm{E}$ & 1994 (1) & no & $4.0-12.5$ \\
\hline Corongiu II & COR II & 155 & 34 & 0.6 & 0.2 & 4.0 & A & $\mathrm{E}$ & 1994 (1) & yes & $0.3-1.2$ \\
\hline Corongiu III & COR III & 201 & 34 & 4.3 & 0.3 & 16.1 & $\mathrm{~A}$ & M & $1994(1)$ & yes & $0.5-2.9$ \\
\hline Cucchinadorza & CUC & 318 & 92 & 17.5 & 1.1 & 16.9 & $\mathrm{E}$ & $\mathrm{E}$ & $1994(1)$ & yes & $0.5-4.0$ \\
\hline $\mathrm{Cuga}^{\circ}$ & CUG & 114 & 58 & 35.0 & 3.1 & 11.3 & A, IR & $\mathrm{E}$ & $1994 / 06(2)$ & yes & $1.8-11.2$ \\
\hline Flumineddu & FLU & 275 & 253 & 1.5 & 0.1 & 12.5 & A, IR, E, IN & $\mathrm{E}$ & $1994(1)$ & no & $0.9-2.4$ \\
\hline Gusana & GUS & 645 & 191 & 59.5 & 2.6 & 22.9 & E & $\mathrm{E}$ & 1994 (1) & yes & $0.7-5.6$ \\
\hline Is Barrocus & IS BAR & 415 & 95 & 11.9 & 1.1 & 10.9 & A & $\mathrm{E}$ & 1994 (1) & yes & $1.0-4.4$ \\
\hline Leni & LEN & 250 & 75 & 20 & 1.1 & 17.7 & A, IR & $\mathrm{E}$ & $1994(1)$ & yes & $0.7-1.4$ \\
\hline $\operatorname{Liscia}^{\circ}$ & LIS & 180 & 284 & 105.0 & 1.3 & 25.7 & $\mathrm{~A}, \mathrm{IR}, \mathrm{IN}$ & $\mathrm{E}$ & 1986/94 (9) & yes & $5.9-12.8$ \\
\hline Medio Flumendosa $^{\circ}$ & MED FLU & 270 & 572 & 300.0 & 4.2 & 23.8 & IR, E, A, IN & M & $1986 / 94(6)$ & yes & $0.3-10.4$ \\
\hline Monteponi & MON & 366 & 8 & 1.0 & 0.1 & 10.1 & $\mathrm{~A}, \mathrm{IN}$ & $\mathrm{E}$ & $1994(1)$ & yes & $1.5-7.2$ \\
\hline Mulargia $^{\circ}$ & MUL & 260 & 179 & 300.0 & 10.5 & 23.8 & A, IR, E, IN & $\mathrm{E}$ & $1985 / 9(12)$ & yes & $0.6-16.4$ \\
\hline Omodeo & $\mathrm{OMO}$ & 118 & 2077 & 148.6 & 13.5 & 11.0 & E, IR, A & E & 1994 (1) & yes & $2.5-9.3$ \\
\hline Pattada $^{\circ}$ & PAT & 561 & 160 & 65.5 & 4.4 & 14.9 & A, IR & $\mathrm{E}$ & $1988 / 06(4)$ & yes & $0.8-4.2$ \\
\hline Posada & POS & 43 & 614 & 27.8 & 3.0 & 9.3 & $\mathrm{IR}, \mathrm{A}$ & E & $1994(1)$ & no & $3.5-8.5$ \\
\hline Punta Gennarta & PUN GEN & 257 & 37 & 9.8 & 0.6 & 15.8 & A, IR & M & 1994 (1) & yes & $0.8-3.8$ \\
\hline Santa Lucia & SAN LUC & 59 & 49 & 3.7 & 0.4 & 8.6 & A, IR & $\mathrm{E}$ & $1994(1)$ & yes & $0.8-3.7$ \\
\hline Simbirizzi & SIM & 33 & 9 & 28.5 & 5 & 5.7 & A, IR & $\mathrm{HE}$ & $1994(1)$ & no & $2.6-4.3$ \\
\hline Sos Canales $^{\circ}$ & SOS & 714 & 16 & 4.3 & 0.3 & 13.2 & A & M & $1991 / 06(7)$ & yes & $1.0-5.7$ \\
\hline Surigheddu & SUR & 50 & 6 & 2.1 & 0.5 & 4.0 & $\mathrm{~A}, \mathrm{IR}$ & $\mathrm{E}$ & 1994 (1) & yes & $1.5-6.3$ \\
\hline Temo $^{\circ}$ & TEM & 226 & 143 & 55.4 & 3.5 & 15.8 & A, IR & E & $1988 / 06(4)$ & yes & $2.0-12.5$ \\
\hline Torrei & TOR & 800 & 14 & 3.0 & 0.2 & 17.6 & A & M & 1994 (1) & yes & $0.6-2.6$ \\
\hline
\end{tabular}

reservoirs, but far enough from the dams to avoid disturbances. They were taken at fixed depths using a Niskin bottle $(0 \mathrm{~m}, 1 \mathrm{~m}, 2.5 \mathrm{~m}, 5 \mathrm{~m}, 7.5 \mathrm{~m}, 10 \mathrm{~m}, 15 \mathrm{~m}$, and deeper than this level at intervals of $10 \mathrm{~m}$ until the bottom was reached). Chlorophyll- $a$ (CHL- $a$ ) and phytoplankton data were transformed in order to represent integrated samples in the photic zone (up to 2.5 times the Secchi disk transparency, SD). Chemical data were expressed as annual averages of integrated values over the entire water column because Sardinian reservoirs are stratified during summer, as are most deep natural lakes (Tab. 1); nevertheless, Sardinian reservoir stratification is often disturbed by water management activities and water level variations. All chemical analyses were performed according to Strickland \& Parsons (1972) except for ammonium (Fresenius et al. 1988) and chlorophyll-a (Goltermann et al. 1978).

Phytoplankton analyses were carried out on samples fixed with Lugol's solution following the Utermöhl method (Sournia 1978; Innamorati 1990). The taxonomic scheme followed Lee (1999). Live samples were observed for species identification, drawing on the following references: Huber-Pestalozzi 1938, 1941, 1942, 1955, 1961, 1968, 1982, 1983; Bourrelly 1972, 1981; Germain 1981; Hustedt 1985; Stulp \& Stam 1985; Komàrek \& Anagnostidis 1989, 1999, 2005; Krammer
\& Lange-Bertalot 1986, 1988, 1991a, b; Hill 1991; Novarino et al. 1994; Renhui et al. 2000; Javornicky 2003).

Biovolume was obtained by multiplying the cell density of each taxon by the unitary cell biovolume of the same taxon, which was obtained by geometrical approximations, after measurement of at least 30 specimens. A single annual biovolume value was then obtained for each taxon by averaging the seasonal values.

\subsection{Data sets}

A "calibration data set" was used to define index parameters, and a "validation data set" was used to confirm the response of the index to the gradient in nutrient concentration using independent data. Finally, a third data set called the "intercalibration data set" was used to compare defined reference conditions and boundaries of quality classes with the values defined in other Mediterranean countries.

The calibration data set was composed of data from 30 Sardinian reservoirs (Fig. 1, Tab. 1). Seasonal data were collected in 1994 and generally include four sampling dates, one for each astronomical season. In the cases of Bau Pressiu and Torrei data from only three samplings were available (no winter data). The use of an annual average was preferred to the single seasonal data 


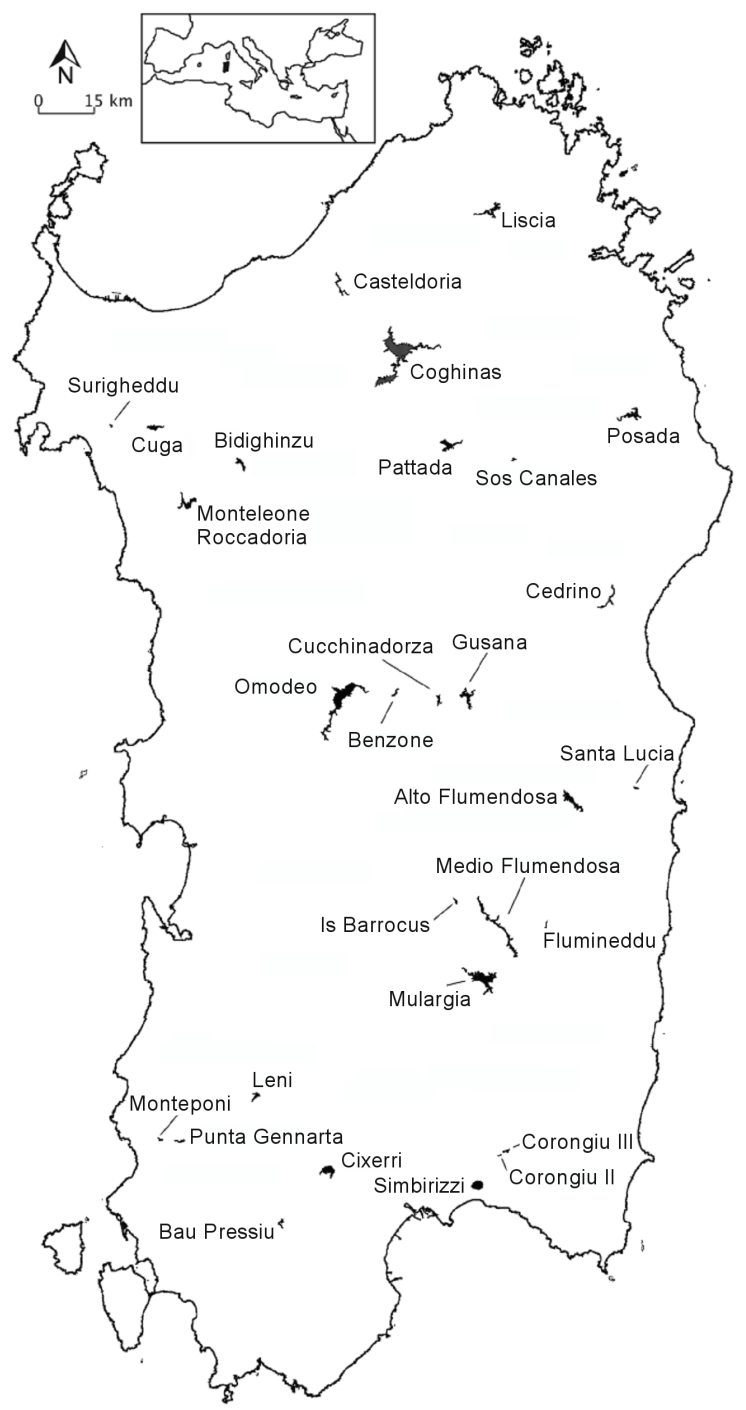

Fig. 1. Location of Sardinian reservoirs.

because it gives a more complete picture of the algal assemblage living in each reservoir, and contains a larger number of taxa: numerical analyses generally show lower estimation errors given a larger number of taxa per sample (ter Braak 1987).

A second data set, used for index validation, includes 48 annual averages taken from 10 reservoirs, spanning from 1 to 12 years per reservoir and averaging between 4 and 11 samples per year (Tab. 1). Each annual mean was used as an individual point for the validation procedure in order to investigate the effect of interannual variability, which had been reported as relevant in other Mediterranean reservoirs (Geraldes \& Boavida 2005; Naselli-Flores \& Barone 2005).

The taxon list was originally composed of 148 taxa, with taxonomic ranks from genus to variety. We used the complete data sets to test the indices proposed by Barbe, Brettum, Catalàn and Salmaso. However, for calibrating and validating the MedPTI index, only taxa that accounted for more than $1 \%$ of the total mean annual biovolume in at least three reservoirs of the calibration data set were considered. When species belonging to the same genera did not reach this threshold, they were merged and the genus as a whole was included in the calibration data set if it accounted for more than $1 \%$ of the total biovolume in at least three reservoirs. The revised taxon list of 44 elements is reported in table 2. Two reservoirs (Flumineddu and Govossai) were discarded because the sum of the biovolumes of the taxa included in the list accounted for less than $70 \%$ of the mean annual biovolume. In fact, the phytoplankton in these reservoirs was dominated by Rhizosolenia eriensis H.L.Sm. in Briggs (Govossai) and species of the genus Monoraphidium Komarkova-Legnerova and Mallomonas Perty (Flumineddu). These taxa were rarely found to be such significant biovolume constituents in the other sampled reservoirs, so they were not included in the MedPTI taxa list. 
Tab. 2. List of selected MedPTI species, their trophic values $(v)$ and indicator values $(i)$. (BAC=Bacillariophyceae; $\mathrm{CHL}=$ Chlorophyceae; $\mathrm{CRY}=$ Cryptophyceae; $\mathrm{CYA}=$ Cyanophyceae; $\mathrm{CON}=$ Conjugatophyceae; DIN=Dinophyceae; $\mathrm{EUG}=$ Euglenophyceae). (+ indicates the presence of the same species in other index lists: Brettum \& Andersen 2004; Salmaso et al. 2006; Willeïn 2007).

\begin{tabular}{|c|c|c|c|c|c|c|c|}
\hline Class & Specie & $v$ & $i$ & Code & Brettum & PTI & TPI \\
\hline CRY & Komma caudata (L. Geitler) D.R.A. Hill & 1.11 & 25.04 & Ko & & & \\
\hline CYA & $\begin{array}{l}\text { Anabaena spiroides Klebahn } \\
\text { Stephanodiscus spp. }\end{array}$ & 1.16 & 30.41 & As & + & & + \\
\hline $\mathrm{BAC}$ & $\begin{array}{l}\text { S. hantzschii Grunow } \\
\text { Stephanodiscus spp. }\end{array}$ & 1.30 & 42.25 & St & + & + & + \\
\hline CYA & Microcystis flos-aquae (Wittrock) Kirchner & 1.38 & 41.36 & Mf & & & + \\
\hline $\mathrm{CHL}$ & Oocystis spp. & 1.39 & 13.12 & Oo & + & + & \\
\hline $\mathrm{CON}$ & Closterium spp. & 1.42 & 25.57 & $\mathrm{Cl}$ & & & \\
\hline CYA & Microcystis spp. & 1.58 & 43.82 & My & & & + \\
\hline CYA & Microcystis aeruginosa (Kützing) Kützing, & 1.64 & 41.71 & Mae & + & & + \\
\hline $\mathrm{CON}$ & Closterium gracile Brébisson ex Ralfs & 1.72 & 14.24 & $\mathrm{Cg}$ & & & \\
\hline CYA & $\begin{array}{l}\text { Anabaena planctonica Brunnthaler } \\
\text { Coelastrum spp. } \\
\text { C. microporum Nägeli }\end{array}$ & 1.76 & 24.32 & Ap & + & & + \\
\hline CHL & $\begin{array}{l}\text { C. pseudomicroporum Korshikov } \\
\text { C. reticulatum (P.A. Dangeard) Senn } \\
\text { Coelastrum spp. }\end{array}$ & 1.78 & 12.37 & Coe & + & + & + \\
\hline CYA & $\begin{array}{l}\text { Woronichinia } \text { spp. } \\
\text { W. naegeliana (Unger) Elenkin } \\
\text { Woronichinia } \text { spp. }\end{array}$ & 1.95 & 10.77 & Wo & + & + & \\
\hline CYA & Aphanizomenon flos-aquae (Linnaeus) Ralfs ex Bornet \& Flahault & 2.1 & 31.46 & Afa & + & + & + \\
\hline BAC & Aulacoseira cf. distans (Ehrenberg) Simonsen & 2.23 & 34.78 & Ad & + & & \\
\hline CHL & Pediastrum simplex Meyen & 2.41 & 28.86 & Ps & & & \\
\hline CRY & Cryptomonas spp. & 2.49 & 14.34 & $\mathrm{Cr}$ & & + & + \\
\hline CYA & Oscillatoria tenuis C. Agardh & 2.51 & 12.07 & Ot & & & \\
\hline $\mathrm{CON}$ & Closterium aciculare $\mathrm{T}$. West & 2.53 & 27.22 & $\mathrm{Ca}$ & & + & \\
\hline EUG & Trachelomonas spp. & 2.55 & 6.74 & $\operatorname{Tr}$ & & & + \\
\hline DIN & $\begin{array}{l}\text { Ceratium hirundinella (O.F. Müller) Dujardin } \\
\text { Cyclotella } \text { spp. } \\
\text { C. atomus } \text { Hustedt }\end{array}$ & 2.58 & 15.19 & $\mathrm{Ce}$ & + & + & \\
\hline $\mathrm{BAC}$ & $\begin{array}{l}\text { C. meneghiniana Kützing } \\
\text { C. radiosa } \text { (Grunow) Lemmermann } \\
\text { C. stelligera } \text { Cleve \& Grunow } \\
\text { Cyclotella } \text { spp. }\end{array}$ & 2.58 & 9.88 & $\mathrm{Cy}$ & + & + & + \\
\hline CRY & $\begin{array}{l}\text { Plagioselmis lacustris (Pascher et Ruttner) Javornický } \\
\text { Anabaena spp. }\end{array}$ & 2.66 & 39.58 & Pl & & + & + \\
\hline CYA & $\begin{array}{l}\text { A. flos-aquae Bréb. Ex Born. Et Flah } \\
\text { Anabaena spp. }\end{array}$ & 2.72 & 26.56 & An & + & & + \\
\hline CYA & Tetraedron minimum (A. Braun) Hansgirg & 2.75 & 83.86 & $\mathrm{Tm}$ & + & & \\
\hline BAC & Aulacoseira ambigua (Grunow) Simonsen & 2.76 & 8.03 & $\mathrm{Aa}$ & + & + & + \\
\hline BAC & Aulacoseira granulata (Ehrenberg) Simonsen & 2.82 & 13.87 & $\mathrm{Ag}$ & & + & + \\
\hline CYA & $\begin{array}{l}\text { Gomphosphaeria aponina Kützing } \\
\text { Scenedesmus spp. } \\
\text { S. acutus } \text { Meyen }\end{array}$ & 2.84 & 16.71 & $\mathrm{Ga}$ & & & \\
\hline CHL & $\begin{array}{l}\text { S. linearis Komárek } \\
\text { S. quadricauda Chodat } \\
\text { Scenedesmus } \text { spp. }\end{array}$ & 2.91 & 11.25 & $\mathrm{Sc}$ & + & + & + \\
\hline CON & Staurastrum spp. & 2.94 & 28.16 & Ss & & + & \\
\hline BAC & $\begin{array}{l}\text { Fragilaria crotonensis Kitton } \\
\text { Aulacoseira spp. }\end{array}$ & 2.95 & 12.09 & $\mathrm{Fc}$ & + & + & + \\
\hline $\mathrm{BAC}$ & $\begin{array}{l}\text { A. granulata var. angustissima (O.F. Müller) Simonsen } \\
\text { Aulacoseira } \text { spp. }\end{array}$ & 3.08 & 41.76 & $\mathrm{Au}$ & & & + \\
\hline $\mathrm{CON}$ & $\begin{array}{l}\text { Staurastrum gracile Ralfs ex Ralfs } \\
\text { Gymnodinium spp. }\end{array}$ & 3.1 & 18.08 & $\mathrm{Sg}$ & + & & \\
\hline DIN & $\begin{array}{l}\text { G. uberrimum (G.J. Allman) Kofoid \& Swezy } \\
\text { Gymnodinium spp. }\end{array}$ & 3.14 & 210.67 & Gy & & + & + \\
\hline CHL & Pediastrum duplex Meyen & 3.21 & 16.37 & $\mathrm{Pd}$ & + & & + \\
\hline
\end{tabular}

(continued) 
Tab. 2. Continuation.

\begin{tabular}{|c|c|c|c|c|c|c|c|}
\hline Class & Specie & $v$ & $i$ & Code & Brettum & PTI & TPI \\
\hline BAC & $\begin{array}{l}\text { Fragilaria } \text { spp. } \\
\text { F. brevistriata Grunow } \\
\text { F. capucina } \text { Desmazières } \\
\text { F. construens } \text { (Ehrenberg) Grunow } \\
\text { F. dilatata } \text { (Brébisson) Lange-Bertalot } \\
\text { F. fasciculata } \text { (C. Agardh) Lange-Bertalot } \\
\text { F. nanana Lange-Bertalot } \\
\text { F. tenera } \text { (W. Smith) Lange-Bertalot } \\
\text { F. ulna } \text { (Nitzsch) Lange-Bertalot } \\
\text { F. vaucheriae (Kützing) J.B. Petersen } \\
\text { Fragilaria } \text { spp. }\end{array}$ & 3.35 & 37.33 & Fr & + & & + \\
\hline CYA & $\begin{array}{l}\text { Planktothrix rubescens (De Candolle ex Gomont) Anagnostidis \& } \\
\text { Komárek }\end{array}$ & 3.36 & 270.38 & $\operatorname{Pr}$ & & + & \\
\hline CYA & Ankistrodesmus sp. & 3.37 & 19.81 & Ak & & & \\
\hline CYA & $\begin{array}{l}\text { Chlorella spp. } \\
\text { Volvox spp. }\end{array}$ & 3.39 & 17.24 & $\mathrm{Ch}$ & & & \\
\hline CHL & $\begin{array}{l}\text { V. aureus Ehrenberg } \\
\text { Volvox spp. }\end{array}$ & 3.4 & 43.91 & Vo & & & \\
\hline DIN & Peridinium spp. & 3.43 & 27.32 & $\mathrm{Pe}$ & & & \\
\hline BAC & Cyclotella ocellata Pantocsek & 3.49 & 23.23 & $\mathrm{Co}$ & & & \\
\hline BAC & Fragilaria ulna var. acus (Kützing) Lange-Bertalot & 3.5 & 42.84 & $\mathrm{Fu}$ & & & \\
\hline CYA & $\begin{array}{l}\text { Ankistrodesmus falcatus (Corda) Ralfs } \\
\text { Sphaerocystis spp. }\end{array}$ & 3.68 & 11.12 & Af & & & \\
\hline CHL & $\begin{array}{l}\text { S. planctonica (Korshikov) Bourelly } \\
\text { Sphaerocystis spp. }\end{array}$ & 3.69 & 25.86 & Sph & & + & \\
\hline
\end{tabular}

A third data set was also used to compare identified reference conditions and class boundaries among countries in an intercalibration procedure on the quality indices used for evaluating lake water quality in the Mediterranean region (ECOSTAT 2003, 2004). Experts from several European Mediterranean countries submitted phytoplankton biovolume results from their analyses of samples taken during 2006 with identical methods. These data were obtained from 30 reservoirs, 6 of which were considered to be in reference condition (i.e., exempt from significant anthropic pressures) and 24 of which were at the high/moderate boundary with respect to trophic status, meaning that phytoplankton composition and biomass were starting to show a relevant deviation from the reference conditions. However, 13 of them are located in the Northern wet area of Spain and Portugal and are thus not completely comparable with truly Mediterranean reservoirs, which suffer from periodic droughts. For this reason, MedPTI was calculated only considering the other 17 sites ( 3 reference sites and 14 at the boundary). Italy participated in the intercalibration exercise with data from three Sardinian reservoirs (Medio Flumendosa, Mulargia and Sos Canales). The reference and boundary values proposed for MedPTI were included in the ECOSTAT procedure (ECOSTAT 2003, 2004) and compared with the values set on the basis of the validation data set. Reference conditions were defined for the intercalibration exercise as the median of the values measured in the reference sites, and the good-moderate boundary was defined as the $5^{\text {th }}$ percentile of the values measured in the sites considered to be close to this boundary, in accordance with national procedures (ECOSTAT 2003, 2004).

\subsection{Multivariate analysis}

To identify the primary gradient(s) controlling the composition of algal assemblages, a Canonical Correspondance Analysis (CCA, ter Braak 1987) was performed using the CANOCO software, version 4.5 (Biometrics - Plant Research International, Wageningen, NL).

The annual average percent abundances included in the calibration data set were square-root transformed before analysis to reduce the influence of the highest values on the ordination (Legendre \& Legendre 1998). Selected constraining variables included watershed area, the averaged value of water temperature, conductivity, $\mathrm{pH}$, alkalinity, the percent of $\mathrm{O}_{2}$ saturation, the concentrations of reactive (RP) and total phosphorus (TP), total nitrogen (TN), ammonium, nitrate, reactive silica $(\mathrm{Si})$, manganese, and iron, lake volume, lake depth $\left(Z_{\mathrm{col}}\right)$ during the samplings, depth of the euphotic $\left(Z_{\text {eu }}\right)$ and mixing $\left(Z_{\text {mix }}\right)$ zones, and the ratios of $Z_{\text {col }} / Z_{\text {mix }}$ and $Z_{\text {mix }} / Z_{\text {eu }}$. A binary variable was also included to distinguish stratified and polymictic reservoirs.

The significance of the variables included in the model was evaluated using a Bonferroni-adjusted permutation test with 999 permutations.

\section{RESULTS AND DISCUSSION}

\subsection{Test of some selected trophic indices}

In general, hydrological variations have a deep impact on phytoplankton communities, and a reductionistic approach based on indices cannot be considered as a general approach for studying, from an eco- 


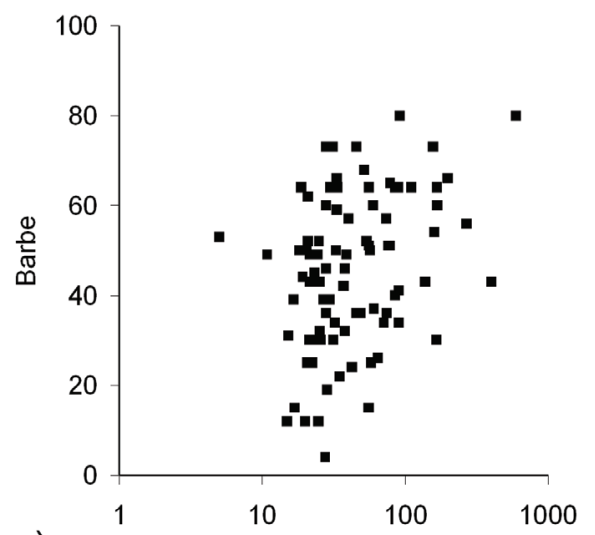

a)

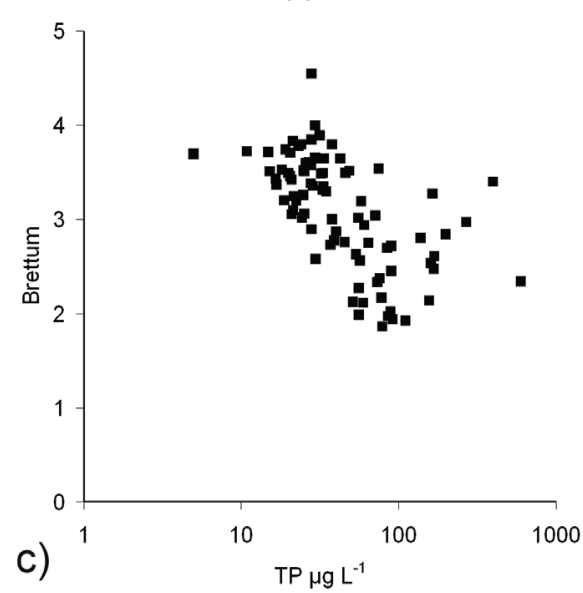

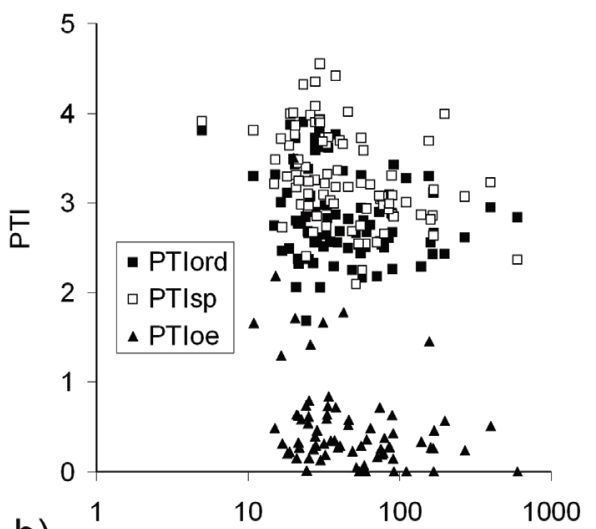

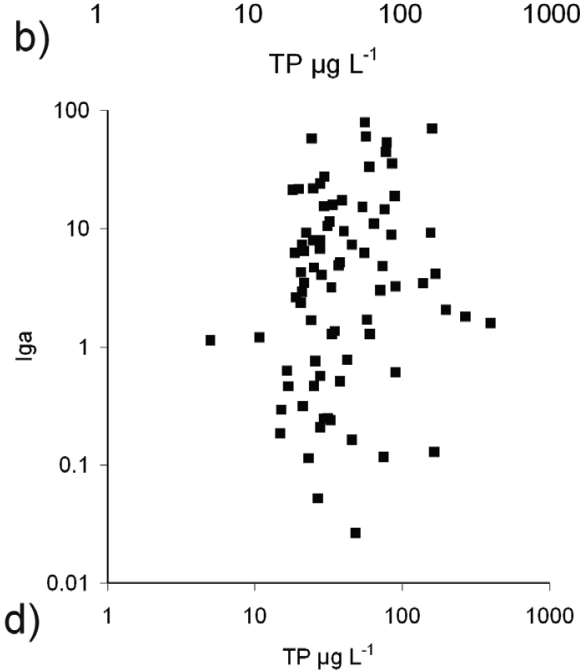

Fig. 2. Comparison between mean annual TP concentration $\left(\mu \mathrm{g} \mathrm{L}^{-1}\right)$ and trophic indices evaluated for all the samples included in the calibration and validation data sets.

logical perspective, phytoplankton distribution and variability. However a number of numerical indices have been developed to infer the ecological quality of European lakes from the composition of their phytoplankton communities. Four of them have since been used in Southern Europe: the Iga or Catalàn index in Spain (Agència Catalana de l'Aigua 2003), the ITP or Barbe index in France (Philippe et al. 2003), a local calibration of the Brettum index in Austria (Dokulil \& Teubner 2006), and the Phytoplankton Trophic Index (PTI) in Italy (Salmaso et al. 2006).

The response of the four indices to the gradient in nutrient concentration in the Sardinian reservoirs, as represented by the mean annual TP concentration, was investigated (Fig. 2) using all the annual data included in the calibration and validation data sets, without species selection. This work represents an attempt at using these indices in Sardinian environments with an enlarged base of data than it was in Marchetto et al. (2008).

The ITP index was originally calibrated using the relative abundance of algal assemblages sampled with a plankton net. As expected, ITP index was not directly applicable to our data, which was obtained by bottle sampling, and the index values did not reflect the TP gradient (Fig. 2a).
Similar results were also obtained in the case of the PTI (Fig. 2b). This index was calibrated on very large and deep $(>100 \mathrm{~m})$ natural lakes, which are mainly oligo- and mesotrophic and difficult to compare with the Sardinian reservoirs. Its species list does not include 14 species frequently found in Sardinian reservoirs, including particular taxa preferring Sardinian eutrophic waters, such as Komma caudata (L. Geitler) D.R.A. Hill, Anabaena spiroides Klebahn, A. planctonica Brunnthaler, Microcystis flos-aquae (Wittrock) Kirchner, $M$. aeruginosa (Kützing) Kützing, Oocystis spp. and Closterium gracile Brébisson ex Ralfs.

On the contrary, the values of the modified Brettum index (Dokulil \& Teubner 2006) correctly reflect the position of the Sardinian reservoirs along the TP gradient (Fig. 2c). However, its predictive value is very limited, as values in the range of 3.0 to 3.4 are obtained for lakes covering the whole TP gradient. This is related in part to the absence on its species list of some taxa commonly found in Sardinian reservoirs, such as Komma caudata, Oscillatoria tenuis C. Agardh, Peridinium sp., Rhodomonas spp., Scenedesmus spp., Sphaerocystis spp. and Trachelomonas spp.

Furthermore, the definition of the Brettum index is more oriented to discerning the trophic status in 
oligotrophic and mesotrophic lakes, such as those found in Scandinavia and in Austria, as opposed to more eutrophic freshwaters such as the Sardinian reservoirs. In fact, in Brettum's species list, each taxon is listed with the probability of finding it in five arbitrary trophic classes based on TP concentration. The five classes are defined by TP ranges of less than 10, 10-20, 20-40, 4060 , and more than $60 \mu \mathrm{g} \mathrm{L}^{-1}$. For comparison, TP values lower than $20 \mu \mathrm{g} \mathrm{L}^{-1}$ were measured in only $12 \%$ of the samples included in our data sets, whereas $44 \%$ and $29 \%$ of the TP values were higher than 40 and $60 \mu \mathrm{g}$ $\mathrm{L}^{-1}$, respectively. Moreover, some taxa (e.g., Ankistrodesmus falcatus (Corda) Ralfs) that are considered typical of oligotrophic lakes by Dokulil \& Teubner (2006) have been found in more eutrophic reservoirs in Sardinia.

Finally, the Iga index was calibrated based on data from Spanish reservoirs similar to those found in Sardinia that cover a similar TP gradient, so the Iga values were expected to correctly reflect the position of the Sardinian reservoirs along the TP gradient. However, no correlation was found between the Iga values and the TP concentrations in our data set (Fig. 2d). The Iga index is based on percentages of algal groups, and though we observed the presence of different species in the same algal group in both Spanish and in Sardinian reservoirs, they showed different trophic preferences. Thus, the trophic "preference" of the whole group was different. In effect, the species commonly found in Sardinian reservoirs (cf. Tab. 2) did not account for more than $70 \%$ of the total annual biovolume in most Spanish reservoirs (Caridad de Hoyos, pers. comm.).

\subsection{Multivariate analyses}

When using CCA, it is very important that the set of environmental variables includes the variable(s) that are truly controlling the species assemblages. Essentially, the CCA only extracts ordination axes that are linear combinations of the environmental variables used in the analysis. If the combined variables do not control the species composition, then the most important gradient cannot be extracted and the analysis will single out a secondary gradient.

To ensure that the CCA correctly reveals the primary gradient in species assemblages, an unconstrained analysis (not shown) was also performed. If a major environmental gradient was related to a hypothetical variable that was excluded from the data sets, the unconstrained and constrained ordinations would not compare. In our case, both site scores and species scores on the first axis of the constrained and unconstrained analysis were well related ( $r=0.98$, Fig. 3d), assuring the correctness of the constrained ordination.

The main gradient identified by the CCA (Figs $3 a, b$, c) is related to a number of interrelated variables, namely the concentration of TN, TP, and RP, oxygen saturation, the depth of the mixing zone, and the ratio
$\mathrm{Z}_{\text {mix }} / \mathrm{Z}_{\mathrm{eu}}$. This central gradient is mainly related to nutrient levels and indicators of production $\left(\mathrm{O}_{2}\right.$ oversaturation).

Repeated significance tests performed on a (not detrended) CCA showed that the above-mentioned variables, together with conductivity, contribute to the ordination at a statistically significant level $(p<0.01)$.

Observing species scores along the nutrient gradient, it appears that Cyclotella ocellata Pantocsek, Oscillatoria tenuis, Tetraedron minimum (A. Braun) Hansgirg, Peridinium spp. and Chlorella spp. are among the taxa characterizing reservoirs with a lower trophic status, whereas the genera Microcystis, Anabaena, Komma, Woronichinia and Stephanodiscus are common in eutrophic reservoirs (Fig. 3a). A second significant gradient can be identified, distinguishing reservoirs that lie on siliceous bedrocks and are richer in Anabaena spp. and Gymnodium sp. from the main reservoir cluster. On the basis of these results, we can assume that the main factor controlling species composition in the Sardinian reservoirs is their TP concentration, and that the geological nature of their catchment may additionally influence species composition. On the contrary, the morphologic and mixing features of the reservoirs contribute secondarily to determining species composition.

In other Mediterranean reservoirs located in Sicily, Naselli-Flores \& Barone (2005) found mixing regime and water uptake to have a strong effect on phytoplankton composition. However, water level changes in Sardinian reservoirs are related mainly to the irregular sequence of arid and relatively wet years. This fluctuation directly influences reservoir volumes, and the trophic status is only indirectly affected by the consequent reduced nutrient dilution.

\subsection{Index definition and calibration}

The proposed index (MedPTI) is based on the weighted averages method (ter Braak 1987) and was calibrated using the calibration dataset described above, after species selection.

For each taxon, the trophic value $(v)$ and the indicator value $(i)$ were calculated.

The trophic value of the $k$-th taxon $\left(v_{k}^{\prime}\right)$ represents the trophic preference of that taxon; it is obtained from the annual mean total phosphorus concentrations (TP) and biovolume (B) of that taxon in all the $n j$-th reservoirs of the calibration data set using the following formula:

$$
v_{k}^{\prime}=\frac{\sum_{j=1}^{n} B_{j, k} \cdot \log \left(T P_{j}\right)}{\sum_{j=1}^{n} B_{j, k}}
$$

The logarithmic transformation was used to stabilise the variance of TP values, as the values were non-normally distributed with left truncation at zero (as all con- 

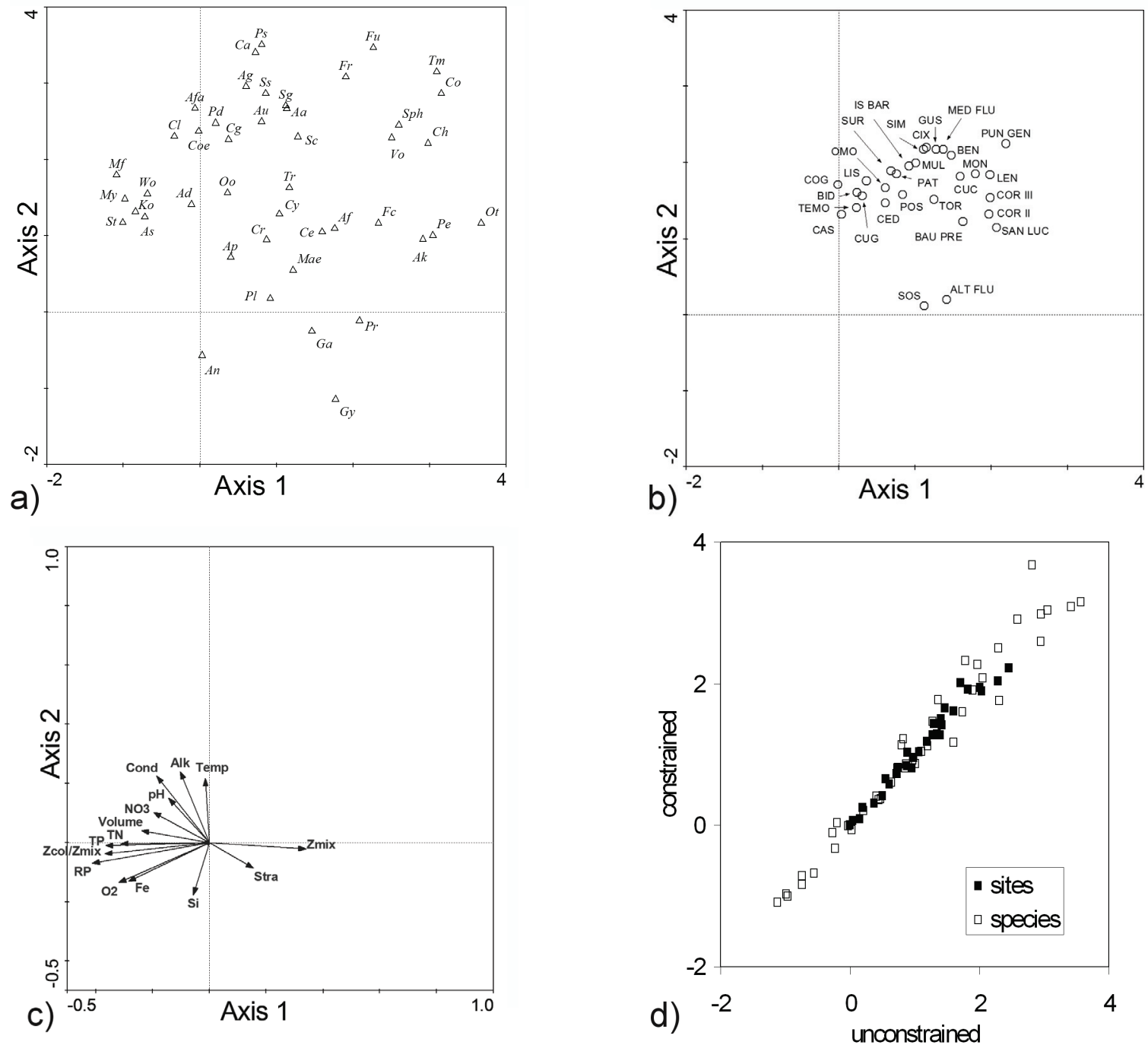

Fig. 3. CCA ordination plot: species scores (a), site scores (b), and loadings of selected variables (c), as well as comparison between site scores along the first axis in constrained and unconstrained ordination (d). Units: standard deviations. Sites and species labels are reported in tables 1 and 2, respectively. Stra: stratification (binary variable).

centration values) and some sporadic high values. Furthermore, the probability of a reservoir having a given trophic status is linearly related to the logarithm of nutrient concentration (e.g., OECD 1982). The log transformation is (implicitly or explicitly) included on most numerical indices that are used to detect the response of planktonic algae (e.g., Brettum 1989; Willeïn 2007) and diatoms (e.g., Wunsam \& Schmidt 1995) to TP levels.

The use of this data transformation slightly raised the proportion of accounted variance $\left(r^{2}\right)$ in the calibration data set and lead to a remarkably higher $r^{2}$ in the validation data set (Tab. 3). To choose the better model when a validation data set is not available, a numerical resampling procedure (e.g., bootstrapping) is usually used (e.g., Birks et al. 1990). However, a validation dataset represents a solid alternative because it allows the direct evaluation of the index performances.
Tab. 3. Explained variance $\left(r^{2}\right)$ of the model depending on data transformation.

\begin{tabular}{|c|c|c|}
\hline $\begin{array}{c}\mathrm{TP} \\
\text { transformation }\end{array}$ & $\frac{r^{2}}{\text { in the calibration data set }}$ & $\frac{r^{2}}{\text { in the validation data set }}$ \\
\hline not transformed & 0.85 & 0.28 \\
\hline logarithmic & 0.88 & 0.39 \\
\hline
\end{tabular}

Because of the short numerical range of log-transformed TP values and of the so-called "shrinking effect" (ter Braak 1987, Marchetto 1994), the resultant numerical range of $v^{\prime}$ values was very narrow. The index was then linearly rescaled to simplify the reading of the results; in this case the index is not used to directly infer $\mathrm{TP}$ values, so that the rescaling equation is completely arbitrary. We arbitrarily selected the following equation in order to obtain decreasing values of the rescaled trophic value $\left(v_{k}\right)$ along the TP gradient in the formulation of MedPTI: 


$$
v_{k}=8.5-3.5 \cdot v^{\prime}
$$

The rescaling equation, although arbitrary, was selected to increase the numerical range of the index from 1.46-1.97 to approximately 1.5-3.4 for better reading, and to have higher values for better water quality. Therefore, the EQR can be obtained by simply dividing the actual value by the reference value.

We decided to avoid an index range between 1 and 5 to prevent confusion between index values and quality classes. In fact, a commonly misunderstood aspect in applying the WFD is that the index ranges and the EQR ranges are, and must be, different: to be WFD-compliant, a numerical index should be monotonically related to water quality, and should have a defined value for reference conditions. WFD-compliant indices used by ECOSTAT (2003) are, for example, the chlorophyll- $a$ concentration (ranging from 0 to $c a 10 \mu \mathrm{g} \mathrm{L}^{-1}$ ) and the percent abundance of non-cyanobacterial phytoplankton (ranging from 0 to $100 \%$ ).

The EQRs should range from 0 to 1 , and the quality classes (numbered from 1 to 5) are defined on the basis of common EQR boundaries defined through the intercalibration exercise. However, there is no need that the indices range specifically between 1 and 5 , and choosing that range for the MedPTI index could lead to the misunderstanding that the index values actually correspond to the quality classes.

The indicator value of the $k$-th taxon $\left(i_{k}\right)$ represents the narrowness of its trophic preference, and consequently its ability to precisely characterise the trophic status of the reservoirs. So, the indicator value $\left(i_{k}\right)$ is the square of the inverse of the "tolerance", as defined by ter Braak (1987):

$$
i_{k}=\frac{\sum_{j=1}^{n} B_{j, k}}{\sum_{j_{1}}^{n} B_{j, k} \cdot D_{j, k}}
$$

where $D_{j, k}$ is the squared difference between the trophic value of the taxon $\left(v_{k}^{\prime}\right)$ (before rescaling) and the logarithm of the TP concentration in the reservoirs:

$$
D_{j, k}=\left[v_{k}-\log \left(T P_{j}\right)\right]^{2}
$$

We decided to use this formulation instead of ter Braak's $t$ for practical reasons: to minimize the rounding errors when squaring and inverting to arrive at the indicator and because with such small values being obtained the latter must be tabulated with a large number of decimals. A list of all trophic weights and indicator values is reported in table 2.

Finally, the value of the MedPTI index in the $i$-th reservoir is obtained from the biovolumes $\left(B_{i, k}\right)$, trophic values $\left(v_{k}\right)$ and indicator values $\left(i_{k}\right)$ of the $m$ species found in that reservoir, on the basis of the following equation:

$$
\operatorname{MedPTI}_{i}=\frac{\sum_{k=1}^{m} B_{j, k} \cdot v_{k} \cdot i_{k}}{\sum_{k=1}^{m} B_{j, k} \cdot i_{k}}
$$

It is important to note that the MedPTI index can only be used if the species listed in table 2 account for a relevant proportion of the total annual biovolume of a given reservoir. In this paper we rejected annual data for which the listed species did not account for at least $70 \%$ of the annual average biovolume.

\subsection{Comparison with literature data}

The MedPTI list of taxa is composed of 44 elements (Tab. 2), with a predominance of Cyanobacteria (11) and Chlorophyceae (11) and Bacillariophyceae (10) and with Conjugatophyceae (5), Dinophyceae (3), Cryptophyceae (3), and Euglenophyceae (1) as less represented classes. Some of the selected taxa have been already reported as trophic indicators in other indices (Tab. 2; Brettum \& Andersen 2004; Salmaso et al. 2006; Willeïn 2007).

Ordering the list on the base of increasing trophic values $v$ (from species which prefer high trophy to those which prefer low trophy), the class composition shows several tendencies: a decrease of Cyanobacteria and parallel increase of Chlorophyceae and Bacillariophyceae, with the presence of Pennales taxa only at the end of the list; a major presence of flagellate species in the central part of the list; Coniugatophyceae presence corresponds to Closterium species at lower $v$ and to Staurastrum species at higher $v$.

Considering three arbitrary blocks of taxa (the first and last fifteen elements and the middle fourteen), it can be observed that elements of Cyanobacteria are more frequent in the first block (7) but are rare in the other two (three in the central and only one in the ending block). Species of the gas-vacuolate genera Microcystis, Anabaena, Woronichinia and Aph. flos-aquae dominate the first block. These species are reported as common in eutrophic inland waters, with a world-wide distribution (Komàrek \& Anagnostidis 1999; Cronberg \& Annadotter 2006). Brettum \& Andersen (2004) indicated very high probabilities $(>50 \%)$ of finding these taxa, with the exception of $W$. naegeliana, in eutrophic and hypereutrophic lakes. They are also abundant in Mediterranean eutrophic reservoirs (Sechi \& Lugliè 1992, 1996; Barone \& Naselli-Flores 1994; Naselli-Flores \& Barone 1998, 2000; Komàrek 2003; Naselli-Flores 2000; Barone 2003) where toxicity has been assessed during their blooms (Cook et al. 2004; Carrasco et al. 2006; Messineo et al. 2008). Chlorococcal non-motile colonial genera are well represented in this first part of the list (Coelastrum, Pediastrum (P. simplex), and Oocystis), contemporary with non-motile slender Closterium and the motile Komma, so that both mixing- and non mixing-tolerant species are considered (Reynolds et al. 
2002). Aulacoseira cf. distans (Ehrenberg) Simonsen and Stephanodiscus spp. are the only diatoms included in this block. They are centric and only the former is colonial. S. hantzschii, one of the merged species, is reported as flushing-tolerant and sensitive to nutrient depletion (Reynolds et al. 2002).

On the contrary to the above block of taxa, the fifteen taxa at the end of the MedPTI list are mainly Chlorophyceae (7) of the genera Chlorella, Sphaerocystis, Ankistrodesmus, Pediastrum (P. duplex), and Volvox. The latter is the only motile chlorophycean genus of the MedPTI list, and it was found to be relevant ( $\geq 1 \%$ of the total annual mean biovolume in 1994) in four Sardinian reservoirs (Corongiu II, Gusana, Pattada, Torrei). The relative maxima were observed in the first two reservoirs in spring (late March) and in the others in autumn (late September), when stratification was not well defined. The importance of this genus is confirmed in Lake Torrei, one of the few oligomesotrophic Sardinian reservoirs (Sechi \& Lugliè 1996), on the basis of data collected monthly during a limnological study conducted from September 1992 to September 1994 (unpublished data). Reynolds et al. (2002) report Volvox as highly light tolerant and sensitive to nutrient deficiency. We propose further investigation and consideration of Volvox species in these respects. Except for Chlorella, the other named chlorophycean genera of the ending block are colonial gelatinous and non-gelatinous forms, a number of whom are reported to be frequent in Sicilian reservoirs (Pediastrum and Sphaerocystis; Barone 2003) and dominant in the mesotrophic natural and artificial lakes of Sicily (Ankistrodesmus, Pediastrum, Sphaerocystis; Naselli-Flores \& Barone, 2000). Dinophyceae are well represented in this last part of the list, with species of the genera Gymnodinium and Peridinium. Naselli-Flores and Barone (2000) highlighted that dinophytes of the genus Peridinium were among the most important species in two mesotrophic Sicilian lakes (one natural and one artificial). In one of the two freshwater environments (Biviere di Cesarò Lake) some small Fragilaria species (now considered to belong to Staurosira and Pseudostaurosira; Williams \& Round, 1987) were also relevant. In general, they are reported in shallow meso- and oligotrophic waterbodies, even if trophic preferences of many species are not yet well defined (e.g., F. crotonensis, Morabito 2005; Hofmann 1994). The other two diatom genera at the end of the MedPTI list are Cyclotella (C. ocellata) and Aulacoseira. The former is also frequently observed in Sicilian reservoirs (Barone 2003). Morabito et al. (2003) noted these species as characteristic of oligo-mesotrophic waters in the southern subalpine lake district, as corroborated by Salmaso (2000, 2003). Salmaso et al. (2006) indicated the appearance of "small centric diatoms" (Cyclotella spp.) among the taxa that had been developed following the Lago Maggiore shift towards oligotrophy. Planktotrix rubescens is the only taxon of
Cyanobacteria in the last block. This species is reported as belonging to the deep-living algal communities of mesotrophic lakes (Adler et al. 2000; Teubner et al. 2003) and was recently detected in Sicilian reservoirs (Naselli-Flores et al. 2007). Its presence has been well documented in Sardinian reservoirs since 1985 due to the intense and toxic blooms caused in lakes Mulargia, Medio Flumendosa and Alto Flumendosa (Sechi \& Lugliè 1989).

The middle group of the MedPTI taxa list is more heterogeneous, with elements belonging to all seven reported classes. It is interesting to highlight that four (Cryptomonas spp., Trachelomonas spp., C. hirundinella and $P$. lacustris) of the six motile (flagellate) taxa of the list fall in this central portion. Cryptophyceae, a cosmopolite class (Klaveness 1988), are present in the list with three genera: Komma, Cryptomonas and Plagioselmis. Barone and Naselli-Flores (2003) observed them frequently in Sicilian reservoirs and found them particularly abundant in winter, when decreased grazing pressure and a reduced light climate occur. Furthermore, they indicate that the significance and population dynamics of these species appear mostly independent of the nutrient concentration; however, in some comparative limnological observations carried out in four freshwater lentic environments, Cryptomonas was found to be more prevalent in the large mesotrophic reservoir of Lake Rosamarina. Cryptomonas was detected in all but two Sardinian reservoirs (Medio Flumendosa and Mulargia), whereas Komma and Plagioselmis were less widely distributed. These taxa were important $(\geq 1 \%$ of the annual mean biovolume in 1994) in 14, 4 and 3 reservoirs, respectively, and in general were observed more frequently in winter samples (especially Cryptomonas).

\subsection{Validation and boundary setting}

To verify that it is able to identify the position of Mediterranean reservoirs along the trophic gradient, the MedPTI was applied to the independent monitoring data included in the above-described validation data set, including 48 annual averages of data taken in 10 reservoirs between 1985 and 2006. The reservoirs are mostly the same as those used for the calibration data set, but the data included in these sets do not overlap.

In the validation data set, the MedPTI values were significantly related to the TP annual mean concentrations; logarithmic transformation of the TP values resulted in a regression coefficient of 0.53 after the exclusion of two outliers. These data come from the eutrophic Lake Bidighinzu that has TP concentrations higher than $0.3 \mathrm{mg} \mathrm{L}^{-1}$. The MedPTI value calculated for these samples ( $\mathrm{ca} 1.5$ ) correctly places them among the eutrophic lakes, but the very high TP concentration found in this lake makes these samples outliers in the relation between TP and MedPTI.

The MedPTI values appear to be split into two groups (Fig. 4): reservoirs with TP concentrations lower 


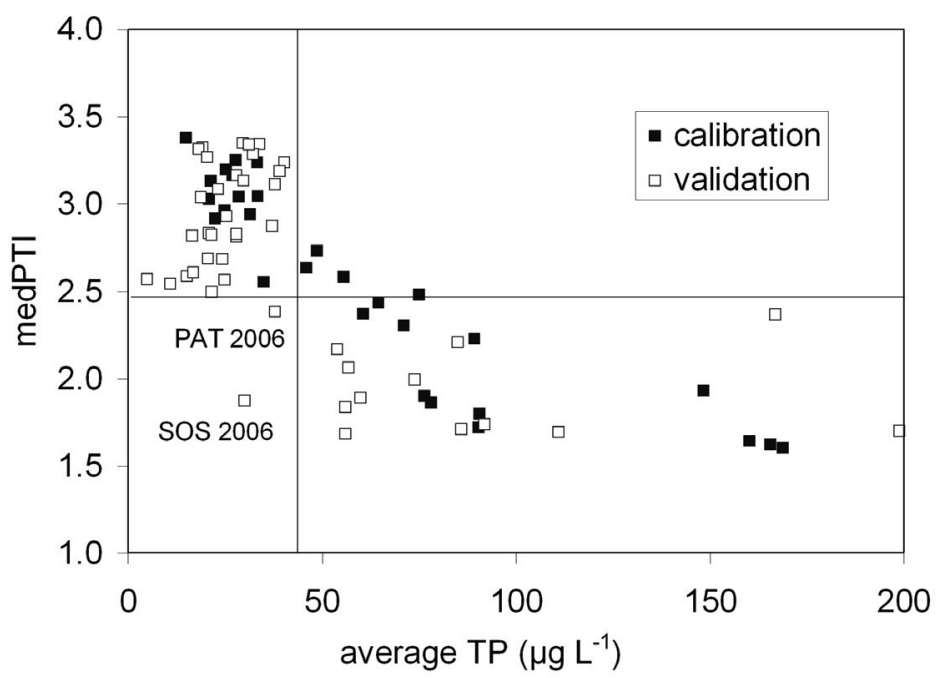

Fig. 4. Relationship between MedPTI trophic index and TP concentration $\left(\mu \mathrm{g} \mathrm{L}^{-1}\right)$ in the calibration and validation reservoirs.

than $40 \mu \mathrm{g} \mathrm{L}^{-1}$ have values higher than 2.45 , whereas reservoirs with higher TP concentrations have MedPTI values lower than 2.45 . This discontinuity in the gradient is used as boundary limit to distinguish reservoirs with good quality status from those with moderate quality status.

In 2006, two reservoirs (Pattada and Sos Canales) showed low MedPTI values and low TP concentrations. In both cases, the species composition and the MedPTI index were close to that found in the previous years (see also Tab. 6), while TP concentration decreased. Different causes may be responsible for these concentration decreases, both natural (higher rainfall) and anthropogenic (watershed and lake management which are able to influence stored water volumes and nutrient input). In these cases, the index correctly classified the reservoirs on the basis of their species composition, even though on the basis of their TP concentration they could have been considered in good or high quality.

This pattern underlines the advantage of an index based on species composition: it can better estimate the ecological quality of waterbodies when subject to strong environmental variations from one year to the next than an index based on nutrient concentrations. Ruggiu et al. (1998) documented that notable changes in the phytoplankton structure of Lago Maggiore took place only after a sufficient period of stable and sensible reduction of nutrients during the oligotrophication process.

The highest MedPTI value (3.38) was shown in Leni Lake, and the values obtained for a small group of reservoirs with low TP concentration ranged between 3.11 and 3.35, with a median value of 3.2. This value was assumed as the reference value for MedPTI and tested in the WFD intercalibration exercise.

To define the other class limits required by the WFD, the technique of equal intervals was employed, as suggested by ECOSTAT $(2003,2004)$. The boundary between "good" and "high" quality classes was set at the average between the reference value and the good/moderate boundary, and the other classes were assumed to have the same range of values. The class limits and the relative EQR are summarized in table 4.

Tab. 4. MedPTI values calculated for the GIG sites.

\begin{tabular}{|c|c|c|c|}
\hline & Lake & Country & MedPTI \\
\hline \multirow{4}{*}{ Reference sites } & Sacele & Rumania & 3.19 \\
\hline & Lefkara & Cyprus & 3.13 \\
\hline & Eugui & Spain & 2.99 \\
\hline & & Median value: & 3.13 \\
\hline \multirow{15}{*}{ 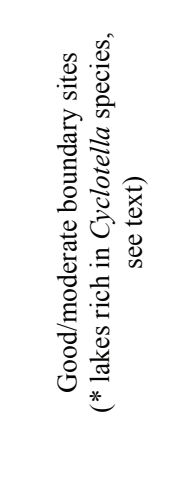 } & Kouris* & Cyprus & $3.20^{*}$ \\
\hline & Asprokremmos* & Cyprus & $3.24 *$ \\
\hline & Negratin* & Spain & $3.27 *$ \\
\hline & Guadalest* & Spain & $3.13 *$ \\
\hline & Talarn & Spain & 2.68 \\
\hline & Izvorul Montelui & Rumania & 2.69 \\
\hline & Aldeavilla & Spain & 2.66 \\
\hline & Medio Flumedosa & Italy & 2.63 \\
\hline & Mulargia & Italy & 2.61 \\
\hline & Guadalmellato & Spain & 2.60 \\
\hline & Pálmaces & Spain & 2.35 \\
\hline & Sos Canales & Italy & 2.41 \\
\hline & Maranhão & Portugal & 2.44 \\
\hline & Yeguas & Spain & 2.73 \\
\hline & & $5^{\text {th }}$ percentile & 2.39 \\
\hline
\end{tabular}

\subsection{Intercalibration exercise}

The WFD requires that the Member States of the European Union take all possible measures to guarantee that all European water bodies reach a "good" or "high" ecological quality by 2015 . The European Commission organized a so-called "intercalibration exercise" to ensure that the definition of the boundaries between quality classes in all Member States are similar to each other. To account for the large environmental heterogeneity of European freshwater, the intercalibration exercise is held in Geographical Intercalibration Groups (GIGs). The Mediterranean GIG includes Portugal, 
Tab. 6. Main trophic OECD descriptors and MedPTI values.

\begin{tabular}{c|cccccc}
\hline Reservoir & & $\begin{array}{c}\text { Mean TP } \\
\left(\mathrm{mg} \mathrm{P} \mathrm{m}^{-3}\right)\end{array}$ & $\begin{array}{c}\text { Mean CHL- } a \\
\left(\mathrm{mg} \mathrm{m}^{-3}\right)\end{array}$ & $\begin{array}{c}\text { Max CHL- } a \\
\left(\mathrm{mg} \mathrm{m}^{-3}\right)\end{array}$ & $\begin{array}{c}\text { Mean SD } \\
(\mathrm{m})\end{array}$ & MedPTI \\
\hline \multirow{2}{*}{ Cuga } & 2006 & 86.1 & 12.8 & 29.8 & 0.77 & $\mathbf{1 . 9 4}$ \\
Cedrino & 2006 & 85.5 & 21.2 & 78.1 & 1.16 & $\mathbf{1 . 8 0}$ \\
& 1991 & 31.0 & 8.8 & 22.8 & 3.27 & $\mathbf{1 . 6 2}$ \\
& 1992 & 33.6 & 10.8 & 40.3 & 3.22 & $\mathbf{1 . 5 3}$ \\
Sos Canales & 1997 & 45.8 & 38.1 & 250.8 & 2.23 & $\mathbf{1 . 8 8}$ \\
& 2005 & 42.6 & 5.3 & 7.1 & 3.25 & $\mathbf{1 . 7 2}$ \\
& 2006 & 29.8 & 9.8 & 28.6 & 1.11 & $\mathbf{1 . 8 9}$ \\
& $1988-89$ & 60.3 & 18.7 & 36.1 & 1.70 & $\mathbf{1 . 8 6}$ \\
& 1997 & 51.8 & 16.2 & 37.5 & 1.20 & $\mathbf{1 . 8 7}$ \\
& 2006 & 38.4 & 6.6 & 14.3 & 1.20 & $\mathbf{1 . 7 5}$ \\
& $1988-89$ & 139.0 & 16.1 & 42.5 & 1.25 & $\mathbf{1 . 9 6}$ \\
& 1997 & 156.5 & 30.9 & 181.9 & 0.81 & $\mathbf{1 . 7 5}$ \\
& 2006 & 57.7 & 3.6 & 7.6 & 1.25 & $\mathbf{1 . 8 5}$ \\
\hline
\end{tabular}

Spain, Malta, Greece, Cyprus, and the arid or semi-arid parts of France, Italy, Slovenia, Bulgaria, and Romania.

Following the WFD procedure, the intercalibration exercise consisted of selecting a number of sites within each country and lake type that were considered to be either in reference condition or at the boundary between good and moderate quality. According to the WFD, reservoirs cannot belong to high ecological quality class, as the dam represents a major hydromorphological pressure; for this reason the boundary between good and high quality classes was not considered. For details of the selection procedure and the approval of the sites, refer to the technical documents prepared by ECOSTAT (2003, 2004).

In the Mediterranean GIG, the intercalibration exercise was carried out by sampling and analyzing the selected reservoirs using the same methods in order to calculate all available indices. The reference value for each index will then be represented by the median value of the index calculated from all reference sites. The class boundary was set to the $5^{\text {th }}$ or $95^{\text {th }}$ percentile (for indices related inversely or directly to the nutrient concentration, respectively) of the values calculated in the reservoirs assumed the boundary between classes.

As previously stated, the MedPTI was calculated for the 17 sites ( 3 reference sites and 14 at the boundary) and the values obtained are listed in table 4 . It should be noted that relatively high MedPTI values were obtained for some lakes reported as being at the good-moderate boundary. In these lakes the phytoplankton assemblages were rich in Cyclotella, a genus found in Sardinia in the reservoirs with the lowest TP levels; consequently, the MedPTI index classifies them among the reference sites.

The reference and boundary values obtained in the exercise were 3.13 and 2.39 (Tab. 5), which are very close to the values given in the previous paragraph.

\subsection{Comparison with OECD trophic classification}

MedPTI was applied to the 5 reservoirs for which data were collected in 2006 (Tab. 6): Cedrino (CED), Cuga (CUG), Pattada (PAT), Temo (TEM) and Sos
Canales (SCN). A sixth reservoir (Bidighinzu) was also sampled, but the phytoplankton composition was dominated by a species of the genus Lagerheimia $\mathrm{R}$. Chodat that was not included in the MedPTI list. Species of this genus are reported as indicators of eutrophy and hypereutrophy by Willeïn (2007) and Brettum \& Andersen (2004), which is in agreement with the trophic state of the Lake Bidighinzu.

Tab. 5. MedPTI class boundaries and EQRs.

\begin{tabular}{lcc}
\hline Class limit & MedPTI & EQR \\
\hline high - good & 2.77 & 0.89 \\
good - moderate & 2.45 & 0.79 \\
moderate - poor & 2.13 & 0.69 \\
poor - bad & 1.81 & 0.59 \\
\hline
\end{tabular}

In table 6, MedPTI results are compared to the trophic evaluations obtained from other parameters typically employed for this purpose (e.g., OECD 1982), considering all available pluriannual data except for those used in MedPTI calibration.

The trophic state detected for the other reservoirs in 2006, in line with the OECD (1982) probabilistic classes, were eutrophy (CUG, CED, TEM) and mesotrophy (PAT, SCN). MedPTI evaluations were mostly in agreement with classifications obtained from the OECD model results. CUG, SOS and TEM were classified by MedPTI values into the poor class, which agrees with those of OECD model. The MedPTI values calculated for TEM in previous years confirm its classification in poor or bad classes. Through application of the OECD model, TEM appears to be more eutrophic on the basis of TP $(55 \%)$ alone, but mesotrophic considering the mean $(60 \%)$ and maximum CHL- $a$ (48\%) in 2006. MedPTI classifies SCN in bad or poor conditions in spite of the wide interannual variations of TP, CHL- $a$ and algal biovolume, which cause it to be evaluated sometimes as mesotrophic and sometimes as eutrophic by the OECD model (Lugliè et al. 1996; Sechi \& Lugliè 1996). 
Finally, PAT showed minor oscillations in all the indicators, with OECD probabilistic classification assigning it to eutrophic or mesotrophic (2006) in different years and the MedPTI index falling in ranges corresponding to poor and bad classes.

In general, there is good agreement between the OECD probabilistic classification and the MedPTI quality classes for reservoirs with a high trophic status. For reservoirs showing great inter-annual variability, the OECD evaluation follows the year-to-year changes, whereas MedPTI, being related to the species composition, consistently classifies them in the poor or bad classes beacuse of the presence of species typical of eutrophic lakes. Because of the resilience of planktonic communities, it is probable that the phytoplankton composition reflects the average trophic status of the previous years. From these preliminary results, it appears that the use of compositional indices like MedPTI can allow the inference of an average quality class.

\section{CONCLUSIONS}

The proposed MedPTI index can be considered a useful tool for evaluating the response of the phytoplankton to changes in nutrient concentration in deep reservoirs in Sardinia, in agreement with the WFD guidelines. The procedure followed in defining the class limits and relative EQR was based on the dataset of the Mediterranean GIG.

The reservoirs used for calibration and validation show a wide range of morphometric characters, watershed natures, and human uses, and consequently a wide choice of possible trophic conditions. Moreover, the use of pluriannual data allowed us to take into account the large interannual variability in trophic status for each reservoir.

The choosen class boundaries actually separate the Sardinian reservoirs used to test the index into quality categories that are in agreement with the OECD trophic classification. Among the parameters considered by this probabilistic model, the index is especially well correlated with TP and CHL- $a$.

The proposed MedPTI list of taxa is composed mainly of Cyanobacteria, Chlorophyceae, and Bacillariophyceae. However, the species list should be updated using new monitoring data. Some limitations in the use of MedPTI are evident, mainly related to the limits of the proposed list of species, which should be enlarged using a larger calibration data set. We recommend the use of this index only for reservoirs with a mean depth greater than $15 \mathrm{~m}$, even though in Sardinia it proved reliable for a number of reservoirs shallower than this threshold. As a general rule it should be assumed that for shallower reservoirs, where water management can profoundly alter the mixing regime and the phytoplankton assemblages, an evaluation should be carried out of the effects of physical parameters on phytoplankton.
The definition of the index is not and cannot be in anyway definitive. Other species with different ecological exigencies can be found in Mediterranean reservoirs or may be present in sites not considered in this study. For this reason, the list of trophic and indicator values given in table 2 should be properly updated. Finally, we think that this index, if properly calibrated, can also be used in other deep reservoirs in Italy and in other Mediterranean countries, but specific tests should be performed to confirm its wider applicability.

\section{ACKNOWLEDGEMENTS}

We thank our colleagues for their co-operation in obtaining the different data sets, especially Dr. Paola Buscarinu and Tomasa Virdis, and Caridad de Hoyos and all the participants of the Mediterranean GIG intercalibration for providing their data. The Autonomous Region of Sardinia provided support to study the Sardinian reservoirs, and this work was also partially supported by the European Union, Project no. GOCE-CT2003-505540 (Euro-limpacs: Integrated Project to evaluate the Impacts of Global Change on European Freshwater Ecosystems).

\section{REFERENCES}

Adler, M., F. Gervais, \& U. Siedel. 2000. Phytoplankton species composition in the chemocline of mesotrophic lakes. Arch. Hydrobiol. Adv. Limnol., 55: 513-530.

Agència Catalana de l'Aigua. 2003. Desenvolupament d'un index integral de qualitat ecologica i regionalització ambiental dels sistemes loacustres de Catalunya. Generalitat de Catalunya, Department de Medi Ambient i Habitatge.

Barone, R., \& L. Naselli-Flores. 1994. Phytoplankton dynamics in a shallow, hypertrophic reservoir (Lake Arancio, Sicily). Hydrobiologia, 289: 199-214.

Barone, R., \& L. Naselli-Flores. 2003. Distribution and seasonal dynamics of Cryptomonads in Sicilian water bodies. Hydrobiologia, 502: 325-3219.

Barone, R. 2003. A critical inventory of freshwater phytoplankton in Sicilian lakes. Bocconea, 16(1): 355-365.

Birks, H.J.B., J.M. Line, S. Juggins, A.C. Stevenson \& C.J.F. ter Braak. 1990. Diatoms and $\mathrm{pH}$ reconstructions. Phil. Trans. r. Soc. London, B327: 263-278

Bourelly, P. 1972. Les algues d'eau douce. Les algues vertes. Tome I. Ed. Boubèe \& Cie, Paris: 572 pp.

Bourelly, P. 1981. Les algues d'eau douce. Algues jaunes et brunes. Tome II. Ed. Boubèe \& Cie, Paris: 517 pp.

Brettum, P. 1989. Alger as indikatorer par vannkvalited $i$ norske innsjoer. Planteplankton. NIVA, Blindern, Oslo.

Brettum, P. \& T. Andersen. 2004. The use of phytoplankton as indicator of water quality. Norwegian Institute for Water Research. O-20032: 33-164.

Carrasco, D., E. Moreno, D. Sanchis, L. Wörmer, T. Paniagua, A. Del Cueto, \& A. Quesada. 2006. Cyanobacterial abundance and microcystin occurrence in Mediterranean water reservoirs in Central Spain: microcystins in the Madrid area. Eur. J. Phycol., 41(3): 281-291.

Cook, M.C., E. Vardaka \& T. Lanaras. 2004. Toxic cyanobacteria in greek freshwaters, 1987-2000: occurrence, toxicity, and impacts in the Mediterranean region. Acta Hydroch. Hydrobiol., 32(2): 107-124.

Cronberg, G. \& H. Annadotter. 2006. Manual on aquatic cyanobacteria. ISSHA: $110 \mathrm{pp}$.

Dokulil, M. \& K. Teubner. 2006. Bewertung der Phytoplanktonstruktur stehender Gewässer gemäß der EU-Wasser- 
rahmenrichtlinie: Der modifizierte Brettum Index. In: DGL-Tagungsbericht 2005 (29.9.-2.10.2005) Karlsruhe: 356-360.

Dokulil, M.T., K. Teubner \& M. Greisberger. 2005. Typenspezifische Referenzbedingungen für die integrierende Bewertung des ökologischen Zustandes stehender Gewässer Österreichs gemäß der EU-Wasserrahmenrichtlinie. Modul 1: Die Bewertung der Phytoplanktonstruktur nach dem Brettum-Index. Projektstudie Phase 3, Abschlussbericht. Unpublished report, Bundesministerium für Landund Forstwirtschaft, Umwelt und Wasserwirtschaft, Wien.

ECOSTAT 2003. Guidance on establishing reference conditions and ecological status class boundaries for inland surface waters. European Commission, Luxembourg.

ECOSTAT 2004. Guidance on the Intercalibration process. European Commission, Luxembourg.

European Commission. 2000. Directive 2000/60/EC of October 232000 of the European Parliament and the Council establishing a framework for community action in the field of water policy. Off J Eur Comm L 327: 1-72.

Fresenius, W.K. E.,W.W. Quentin \& W. Scheneider. 1988. Water analysis. A practical guide to physico-chemical and microbiological water examination and quality assurance. Springer-Verlag, Berlin: 320 pp.

Geraldes, A.M. \& M. J. Boavida. 2005. Seasonal water level fluctuations: implications for reservoir limnology and management. Lakes \& Reservoirs: Research and Management, 10: 59-69.

Germain, H. 1981. Flore des Diatomées: eaux douces et saumâtres. Soc. Nouv. Ed. Boubée, Paris.

Goltermann, H.L., R. S. Clymo \& M. A. M. Ohnstad. 1978. Method for physical and chemical analysis of fresh waters. I.B.P. N. 8. Blackwell Scientific Publications, Oxford: $214 \mathrm{pp}$.

Hill, D.R.A. 1991. Chroomonas and other blue-green Cryptomonads. J. Phycol., 27(1): 133-145.

Hofmann, G. 1994. Aufwuchs-Diatomeen in Seen und ihre Eignung als Indikatoren der Trophie. Bibliotheca Diatomologica. Band 30. J. Cramer, Berlin.

Huber-Pestalozzi, G. 1938-1983. Das phytoplankton des Süßwassers. 1. Teil, Allgemeiner Teil blaualgen. Bakterien. Pilze, 1938, 342 pp; 2. Teil, Chrysophyceen. Farblose Flagellaten Heterokonten, 1941, 365 pp; 2. Teil, 2 Hälfte, Diatomeen, 1942, 549 pp; 4. Teil, Euglenophyceen, 1955, 1135 pp; 5. Teil, Chlorophyceae (Grünalgen). Ordnung: Volvocales, 1961, 744; 3. Teil, Cryptophyceae, Chloromonadophyceae, Dinophyceae, 1968, 322 pp; 8. Teil, 1. Hälfte, Conjugatophyceae, Zignematales and Desmidiales (excl. Zygnemataceae), 1982, 543 pp; 7. Teil, 1. Hälfte, Chlorophyceae (Grünalgen). Ordnung: Chlorococcales, 1983, 1044 pp, E. Schweizerbart'sche Verlagsbuchhandlung (Nägele u. Obermiller), Stuttgard.

Hustedt, F., 1985. The Pennate Diatoms. Koeltz Scientific Books Koenigstein.

Innamorati, M. 1990. Misurazione dell'irradianza. In: Innamorati, M., Ferrari, I., Marino, D. and Ribera D'Alcalà, M. (Eds), Metodi nell'ecologia del plancton marino. Nova Thalassia, 11: 11-67.

Javornicky, P. 2003. Taxonomic notes on some freshwater planktonic Cryptophyceae based on light microscopy. In: Naselli-Flores, L., Padisàk J., Dokulil M.T. (Ed.), Phytoplankton and equilibrium concept: the ecology of steadystate assemblages. Kluwer Academic Publishers: 271-283.

Klaveness, D. 1988. Ecology of the Cryptomonadida - a first review. In: Sandgren, C.D. (Ed.), Growth and reproductive strategies of freshwater phytoplankton, Cambridge University Press, New York: 105-133.

Komàrek, J. \& K. Anagnostidis 1989. Modern approach to the classification system of Cyanophytes 4 - Nostocales. Arch. Hydrobiol. Suppl. 82(3) (Algological Studies 56): 247345 .
Komàrek, J. \& K. Anagnostidis 1999. Süßwasserflora von Mitteleuropa, Cyanoprokaryota. 1. Teil Chroococcales. Gustav Fischer: 548 pp.

Komàrek, J. \& K. Anagnostidis. 2005. Süßwasserflora von Mitteleuropa, 2. Teil/end Part: Oscillatoriales. Gustav Fischer: $759 \mathrm{pp}$.

Komàrek, J. 2003. Areas of distribution in Cyanobacteria: specificity of the cyanoprocaryotic microflora in the Mediterranen region. Bocconea Herbarium Mediterraneum Palermitanum, 16(1): 341-353.

Krammer, K. \& H. Lange-Bertalot. 1986-1991. Süßwasserflora von Mitteleuropa. Bacillariophyceae. 2/1: Naviculaceae, 1986, 876 pp; 2/2 Bacillariaceae, Epithemiaceae, Surirellaceae, 1988, 596 pp; 2/3: Centrales, Fragilariaceae, Eunotiaceae, 1991, 576 pp; 2/4 Achnantaceae, 1991, 437 pp Gustav Fisher verlag, Stuttgard.

Lee, R.E. 1999. Phycology. Third edition. Cambridge University Press: $614 \mathrm{pp}$.

Legendre, P. \& L. Legendre. 1998. Numerical ecology. Second edition. Elsevier, Amsterdam, The Netherlands.

Lugliè, A., G.P. Mameli \& N. Sechi 1996 Indagine limnologia pluriennale (dal 1991 al 1993) sul lago artificiale Sos Canales (Sardegna settentrionale). Atti del $11^{\circ}$ Congresso A.I.O.L. - Sorrento, 26-28 ottobre 1994: 479-489.

Marchetti, R., R. Barone, S. Calvo, A. Lugliè, L. NaselliFlores \& N. Sechi. 1992. Studies on Italian reservoirs. Mem. Ist. ital. Idrobiol., 50: 337-363.

Marchetto, A., B.M. Padedda, M.A. Mariani, F. Buzzi, A. Lugliè, P. Buscarinu, N. Sechi \& A. Dal Miglio. 2008. Confronto tra indici di qualità basati sul fitoplancton per l'implementazione della "WFD" direttiva 2000/60/CE ai laghi italiani. Atti A.I.O.L., 19(2): 309-313.

Marchetto, A. 1994. Rescaling species optima estimated by weighted averaging. J. Paleolimnol., 12: 155-162.

Messineo, V., S. Bogialli, S. Melchiorre, N. Sechi, A. Lugliè, P. Casiddu, M.A. Mariani, B.M. Padedda, A. Di Corcia, R. Mazza, E. Carloni \& M. Bruno. (2008). Cyanobacterial toxins in Italian freshwaters. Limnologica: (in press).

Morabito, G. 2005. Prospettive e problemi nello sviluppo di indici di qualità ecologica basati sul fitoplancton in relazione all'applicabilità della Direttiva 2000/60/CE. Biologia Ambientale, 19(1): 71-79.

Morabito, G., A. Oggioni \& P. Panzani. 2003. Phytoplankton assemblages at equilibrium in large and deep subalpine lakes: a case study from Lago Maggiore (N. Italy). Hydrobiologia, 502 (Dev. Hidrobiol. 172): 37-48.

Moss, B. 2008 The Water Framework Directive: total environment or political compromise? Sci. total Environ. doi: 10.1016/j.scitotenv. 2008.04.029

Naselli-Flores, L. 2000. Phytoplankton assemblages in twentyone Sicilian reservoirs: relationships between species composition and environmental factors. Hydrobiologia, 424: 1-11.

Naselli-Flores, L. 2003. Man-made lakes in Mediterranean semi-arid climate: the strange case of Dr Deep Lake and Mr Shallow Lake. Hydrobiologia, 506-509: 13-21.

Naselli-Flores, L. \& R. Barone. 1998. Phytoplankton dynamics in two reservoirs with different trophic state (Lake Rosamarina and Lake Arancio, Sicily, Italy). Hydrobiologia, 369/370: 163-178.

Naselli-Flores, L. \& R. Barone. 2000. Phytoplankton dynamics and structure: a comparative analysis in natural and man-made water bodies of different tropic state. Hydrobiologia, 438: 65-74.

Naselli-Flores, L. \& R. Barone. 2005. Water-level fluctuations in Mediterranean reservoirs: setting a dewatering threshold as a management tool to improve water quality. Hydrobiologia, 548: 85-99.

Naselli-Flores, L., R. Barone, I. Chorus, \& R. Kurmayer. 2007. Toxic cyanobacterial blooms in reservoirs under a semiarid Mediterranen climate: the magnification of a 
problem. Wiley Periodicals, Inc. Environ Toxicol., 22: 399-404.

Novarino, G., I.A.N. Lucas \& S. Morrall. 1994. Observations of the genus Plagioselmis (Cryptophyceae). Cryptogamie. Algologie 15(2): 87-107.

OECD, 1982. Eutrophication of waters: monitoring, assessment and control. OECD Publications, $\mathrm{N}^{\circ}$ 42077, Paris: $154 \mathrm{pp}$.

Padisák, J., G. Borics, I. Grigorszky \& E. Soróczki-Pintér. 2006. Use of Phytoplankton Assemblages for Monitoring Ecological Status of Lakes within the Water Framework Directive: The Assemblage Index. Hydrobiologia, 553(1): 1-14.

Philippe, M., V. Vey \& J. Barbe. 2003. Actualisation de la méthode de diagnose rapide des plans d'eau. Analyse critique des indexes de qualité des lacs et propositions d'indexes de fonctionnement de l'ecosystème lacustre. Cemagref, Lyon: $106 \mathrm{pp}$.

Renhui, L., M. Watanabe \& M.M. Watanabe. 2000. Taxonomic studies of planktic species of Anabaena based on morphological characteristic in cultured strains. Hydrobiologia, 438: 117-138.

Reynolds, C. S. 2002. Ecological pattern and ecosystem theory. Ecological modelling, 158: 181-200.

Reynolds, C.S., V. Huszar, C. Kruk, L. Naselli-Flores \& S. Melo. 2002. Towards a functional classification of the freshwater phytoplankton. J. Plankton Res., 24(5): 417-428.

Riedmüller, U., E. Hoehn, B. Nixdorf \& U. Mischke. 2006. Bewertung der natürlichen Seen Deutschlands anhand des Phytoplanktons. Deutsche Gesellschaft für Limnologie (DGL). Tagungsbericht 2005 (Karlsruhe), Berlin.

Ruggiu, D., G. Morabito, P. Panzani \& A. Pugnetti. 1998. Trends and relations among basic phytoplankton characteristics in the course of the long-term oligotrophication of Lake Maggiore (Italy). Hydrobiologia, 369/370: 243-257.

Salmaso, N., G. Morabito, F. Buzzi, L. Garibaldi, M. Simona \& R. Mosello. 2006. Phytoplankton as an indicator of the water quality of the deep lakes south of the Alps. Hydrobiologia, 563: 167-187.

Salmaso, N. 2000. Factors affecting the seasonality and distribuction of cyanobacteria and chlorophytes: a case study from the large lakes south of the Alps, with special reference to Lake Garda. Hydrobiologia, 438: 43-63.

Received: July 2008

Accepted: December 2008
Salmaso, N. 2003. Life strategies, dominance patterns and mechanisms promoting species coexistence in phytoplankton communities along complex environmental gradients. Hydrobiologia, 502 (Dev. Hidrobiol. 172): 13-36.

Sas, H. 1989. Lake restoration by reduction of nutrient loading. Expetations, experiences, extrapolations. Academia Verlag Sankt Augustin: 519 pp.

Sechi, N. \& A. Lugliè. 1989. Lo stato trofico dei Laghi Mulargia e Flumendosa. Atti del Convegno "La qualità dell'acqua in Sardegna. Il problema dell'eutrofizzazione: cause, conseguenze, rimedi", Cagliari, 15-16 maggio 1986: 131-145.

Sechi, N. \& A. Lugliè. 1992. Limnological studies on manmade lakes in Sardinia (Italy). Mem. Ist. ital. Idrobiol., 50: 365-381.

Sechi, N. \& A. Lugliè. 1996. Phytoplankton in Sardinian reservoirs. Giornale Botanico Italiano, 130 (4-5-6): 977-994.

Sournia, A. 1978. Phytoplankton manual. Monographs on oceanographic methodology. UNESCO.

Stulp, B.K. \& Stam, W.T. 1985. Taxonomy of the genus Anabaena (Cyanophyceae) based on morphological and genotypic criteria. Arch. Hydrobiol. Suppl. 71, 1/2 (Algological Studies 38/39): 257-268.

Strickland, J.D.H. \& T.R. Parsons. 1972. A practical handbook seawater analysis. Bull. Fish. Res. Board Can., 167, Ottawa: 310 pp.

ter Braak, C.J.F. 1987. The analysis of vegetation-environment relationships by canonical correspondence analysis. Vegetatio, 69: 69-77.

Teubner, K., M. Tolotti, S. Greisberger, H. Morscheid, T.M. Dokulil \& H. Moscheid. 2003. Steady state phytoplankton in a deep pre-alpine lake: species and pigments of epilimnetic versus metalimnetic assemblages. Hydrobiologia, 502 (Dev. Hidrobiol. 172): 49-64.

Willeïn, E. 2007. VÄXTPLANKTON I SJÖAR Bedömningsgrunder Institutionen för Miljöanalys. Rapport 2007:5.

Williams D.M. \& F.E. Round. 1987. Revision of the genus Fragilaria. Diatom Research, 2(2):267-288.

Wunsam, S. \& R. Schmidt. 1995. A diatom-phosphorus transfer function for Alpine and pre-alpine lakes. Mem. Ist. ital. Idrobiol. 53: 85-99. 